\title{
Sistem Informasi Manajemen Terhadap Pengambilan
}

\section{Keputusan di Lembaga Pendidikan Islam}

\author{
Ratna Kawuri \\ $185100048 p$ \\ Fakultas Komputer \\ ratnakawuri.student@umitra.ac.id
}

\begin{abstract}
In keeping with the times today that in the management of human resources effectively, every organization is absolutely necessary to create a human resources information system for the development of information systems could affect decision-making in an institution. Expected decisionmaking is a process towards better so with pegetahuan accruing from the information system will add to the discourse, consideration and finally decided appropriately. For information system consists of components supporting educational institutions to provide information needed by decision-makers when making educational activities
\end{abstract}

Keywords: Decision Making, Management Information Systems

\section{Pendahuluan}

Perubahan teknologi ditandai dengan perkembangan yang pesat dalam inovasi teknologi dan komunikasi. Perubahan tersebut menyebabkan setiap lembaga untuk mampu berdiri dan siap menghadapi persaingan. Kebutuhan manusia akan informasi amatlah penting

Selaras dengan perkembangan zaman Sondang menyampaikan bahwa dalam pengelolaan sumber daya manusia secara efektif, setiap organisasi mutlak perlu menciptakan suatu sistem informasi sumber daya manusia. ${ }^{1}$ Oleh karena itu perkembangan sistem informasi akan dapat diimbangi dengan adanya sumber daya manusia. Namun harus tetap diwaspadai bahwa dalam setiap perubahan perlu adanya pengawasan yang cermat dari pihak-pihak terkait. Sehingga tetap perlu adanya pihak yang memiliki wewenang lebih tinggi dari sekedar sumber daya manusia, maka perlu adanya manajer yang mengatur manajemen dalam lembaga tersebut. Berikut disebut dengan sistem

\footnotetext{
${ }^{1}$ Sondang P. Siagian, Manajemen Sumber Daya Manusia, (Jakarta: Bumi Aksara, 2003), 9
} 
informasi manajemen sumber daya manusia. Adanya system informasi manajemen sumber daya manusia dibangun untuk membantu berjalannya organisasi, dimana didalamnya tercantum perencanaan, pengorganisasian, dan pengendalian. Secara akurat system informasi manajemen harus mampu memberikan informasi mengenai kondisi riil organisasi sehingga mampu menunjang peningkatan kualitas suatu organisasi/lembaga dalam bidang teknologi maupun sumber daya manusia.

Jika diterima pendapat bahwa salah satu tantangan yang akan dihadapi oleh umat manusia di masa depan adalah untuk menciptakan organisasi yang semakin beraneka ragam tetapi sekaligus menuntut pengolahan yang semakin efisien, efektif dan produktif, harus pula diterima pendapat bahwa ketergantungan organisasi pada manajemen sumber daya manusia yang semakin bermutu tinggi akan semakin besar pula. Antar keduanya harus mampu saling mengimbangi agar tercipta keselarasan.

\section{Sistem, Teknologi Informasi, dan Sistem Informasi Manajemen}

\section{Sistem}

Sistem adalah suatu kesatuan usaha yang terdiri dari bagian-bagian yang berkaitan satu sama lain yang berusaha mencapai suatu tujuan dalam suatu lingkungan kompleks. Berdasarkan pengertian tersebut menunjukkan bahwa adanya bagian dan hubungan antar bagian tersebut (kerja sama). Selain itu system berupaya untuk mencapai tujuan dimana upaya pencapaian tujuan ini akan menimbulkan dinamika, perubahan yang terus menerus perlu dikembangkan dan dikendalikan. Pengertian sistem dapat digambarkan sebagai berikut:

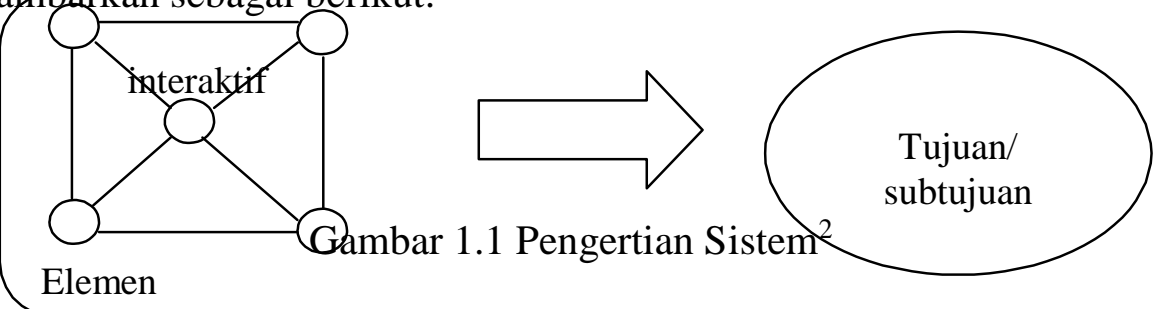

${ }^{2}$ Marimin, dkk, Sistem Informasi Manajemen Sumber Daya Manusia, (Jakarta: Grasindo, 2006), 2 . 
Pengertian sistem juga disampaikan oleh beberapa ahli sebagaimana yang dikutip oleh Eti Rochaety sebagai berikut:

a. Sistem adalah seperangkat unsur yang saling berhubungan dan saling mempengaruhi dalam satu lingkaran tertentu. (Ludwig, 1997)

b. Sistem adalah sekumpulan elemen yang saling berhubungan untuk mencapai suatu tujuan. (A. Rapoport, 1997)

c. Sistem adalah setiap kesatuan secara konseptual atau fisik yang terdiri dari bagian-bagian yang saling mempengaruhi. (L. Ackof, 1997)

d. Sistem merupakan bagian-bagian yang beroperasi secara bersama-sama untuk mencapai beberapa tujuan. (Gordon B. Davis, 1995)

e. Sistem yaitu sekelompok elemen yang terintegrasi untuk mencapai suatu tujuan. (Raymond McLeod, 2001)

f. Ryan (1968) System is any identifiable asswemblage of element (object, person, activities, information records, etc) wich are interrelated by proces or stucture and wich are presumed to function as an organizational entity generating on observable (or sometimes merely inferable) product.

g. William A. Shorde (1995) dalam bukunya Organization and Management menyebutkan ada sekitar enam siri sebuah sitem, yaitu perilaku berdasarkan tujuan tertentu, keseluruhan, keterbukaan, teerjadii transformasi, terjadi korelasi, memiliki mekanisme kontrol artinya terdapat kekuatan yang mempersatukan dan mempertahankan sistem yang bersangkutan.

h. Menurut Budi Sutedjo (2002) sistem adalah kumpulan elemen yang saling berhubungan satu sama lain yang membentuk satu kesatuan dalam usaha mencapai suatu tujuan. ${ }^{3}$

Berdasarkan pendapat para ahli diatas maka dapat disimpulkan pengertian sistem adalah kumpulan elemen-elemen yang saling berhubungan, saling berpengaruh, saling terintegrasi, dan beroperasi secara bersama-sama untuk mencapai suatu tujuan tertentu dalam suatu kompleks. Sedangkan sifat-sifat dasar dari suatu sistem adalah:

${ }^{3}$ Ety Rocaety, dkk, system Informasi Manajemen Pendidikan, (Jakarta: PT Bumi Aksara, 2005) hal 2-3 
1. Pencapaian tujuan, orientasi pencapaian tujuan akan memberikan sifat dinamis kepada sistem, memberi ciri perubahan yang terus menerus dalam usaha mencapai tujuan.

2. Kesatuan usaha, mencerminkan suatu sifat dasar dari sistem, dimana hasil keseluruhan melebihi dari jumlah bagian-bagiannya atau sering disebut konsep sinergi.

3. Keterbukaan terhadap lingkungan, lingkungan merupakan sumber kesempatan maupun hambatan pengembangan. Keterbukaan terhadap lingkungan membuat penilaian terhadap suatu sistem menjadi relatif atau yang dinamakan equifinality atau pencapaian tujuan suatu sistem tidak mutlak harus dilakukan dengan satu cara terbaik. Tetapi pencapaian tujuan suatu sistem dapat dilakukan melalui berbagai cara sesuai dengan tantangan lingkungan yang dihadapi.

4. Transformasi, merupakan proses perubahan input menjadi output yang dilakukan oleh sistem. Proses transformasi diilustrasikan pada gambar dibawah ini.

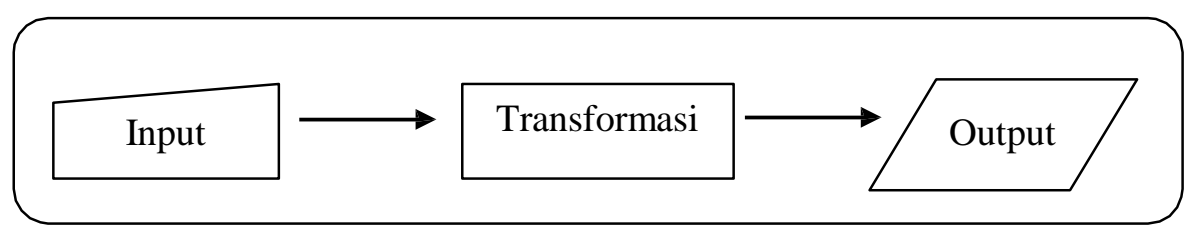

Gambar 1.2 Proses transformasi input menjadi output ${ }^{4}$

5. Hubungan antar bagian, kaitan antara subsistem inilah yang akan memberikan analisis sistem, suatuu dasar pemahaman yang lus.

6. Sistem ada berbagai macam, antara lain sistem terbuka, sistem tertutup, dan sistem dengan umpan balik.

7. Mekanisme pengendalian, mekanisme ini menyangkut sistem umpan balik yang merupakan suatu bagian yang memberi informasi kepada sistem mengenai efek dari perilaku sistem terhadap pencapaian tujuan atau pemecahan persoalan yang dihadapi. Skema proses transformasi

${ }^{4}$ Marimin, dkk, Sistem Informasi. . . ., 2 
sistem dengan mekanisme pengendalian disajikan pada gambar dibawah ini.

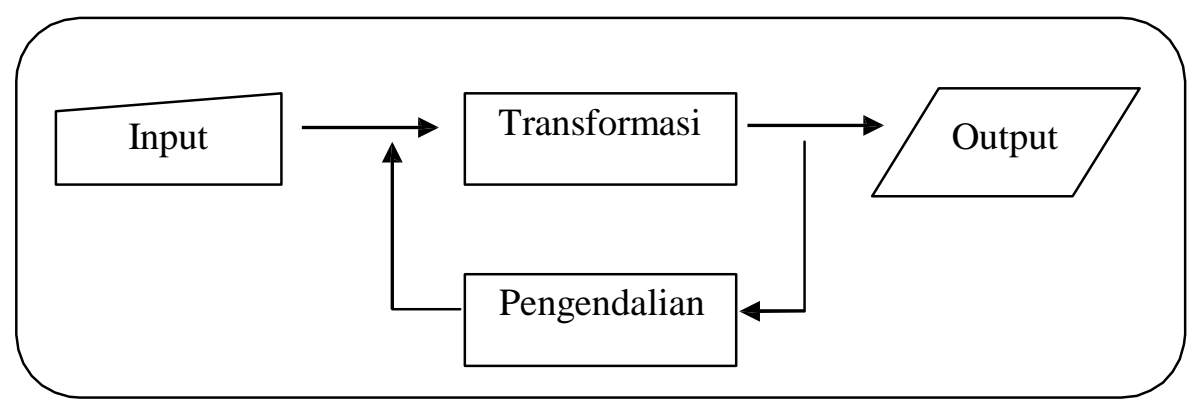

Gambar 1.3 Skema proses transformasi sistem dengan mekanisme pengendalian $^{5}$

Jenis sistem secara umum terdiri dari sistem terbuka dan sistem tertutup (Open-Loop and Closed-Loop System). Sistem terbuka adalah sistem yang tidak memiliki sasaran, pengendalian mekanis, dan umpan balik. Sedangkan sistem tertutup yaitu sistem yang memiliki sasaran, pengendalian mekanis, dan umpan balik. Kedua jenis sistem tersebut dapat dilihat dalam gambar dibawah ini:

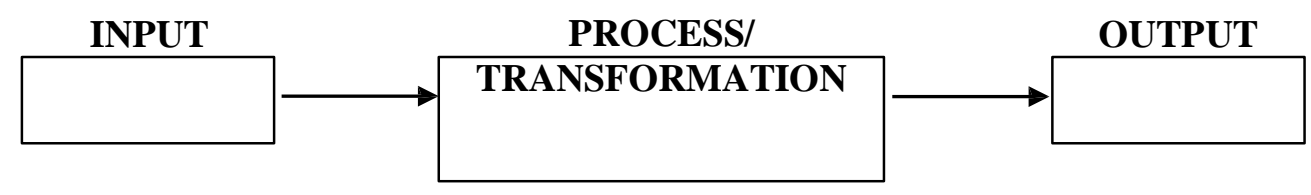

Gambar 1.4 Open-Loop System (Sistem Terbuka)

${ }^{5}$ Marimin, dkk, Sistem Informasi. . . , , 3 


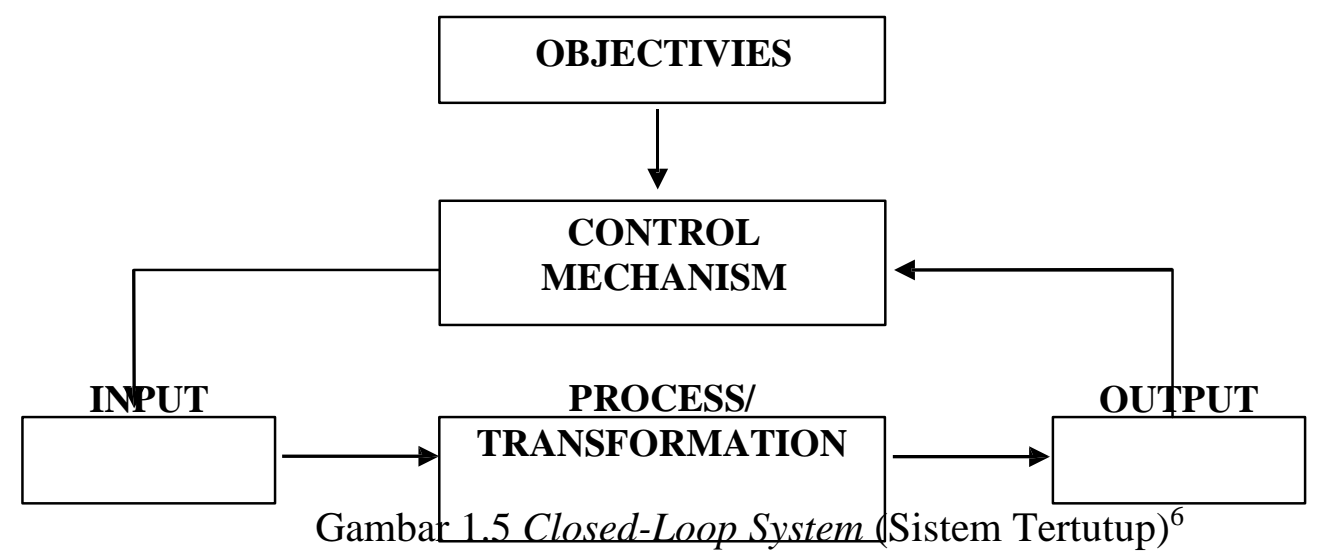

Dari kedua jenis sistem tersebuut dapat dibedakan secara jelas bahwa sistem terbuka tidak memiliki sasaran, kontrol mekanisme, maupun umpan balik. Sebaliknya untuk jenis sitem tertutup masing-masing memiliki sasaran yang jelas, pengendalian mekanisme dan umpan balik.

\section{Teknologi Informasi}

Pada era reformasi seperti sekarang ini, informasi sudah menyentuh seluruh segi kehidupan baik individual, kelompok, maupun organisasi. Ditingkat individu aneka ragam informasi dibutuhkan seperti kebutuhan akan pendidikan, kesehatan, lapangan pekerjaan, maupun jenis produk atau jasa lainnya. Suatu system informasi ada karena digunakan untuk memproduksi informasi dan atau mendukung atau mengotomatiskan kerja yang dilakukan oleh sistem-sistem kerja. ${ }^{7}$ Beberapa pakar mengemukakan pendapatnya dalam menjelaskan tentang pengertian informasi, sebagimana yang telah dikutip oleh Eti Rochaety berikut ini:

a. Adapun pengertian tentang informasi, yaitu data yang telah diproses kedalam suatu bentuk yang mempunyai arti bagi penerima dan memiliki nilai nyata yang dibutuhkan untuk proses pengambilan keputusan saat ini maupun saat mendatang (Gordon B. Davis, 1995)

b. Sedangkan informasi menurutBudi Sutedjo (2002:168) merupakan hasil pemrosesan data yang diperoleh dari setiap elemen sistem tersebut menjadi bentuk yang mudah dipahami dan merupakan pengetahuan yang relevan dan dibutuhkan dalam pemahaman fakta-fakta yang ada.

\footnotetext{
${ }^{6}$ Ety Rocaety, dkk, system Informasi . . . , 3

${ }^{7}$ Jogiyanto H. M., Model Kesuksesan Sistem Informasi Tegnologi, (Yogyakarta: ANDI, 2007), 
c. Informasi yaitu sebuah pernyataan yang menjelaskan suatu peristiwa (suatu objek atau konsep) sehingga mannusia dapat membedakan sesuatu dengan yang lainnya (Samuel Elion, 1992). ${ }^{8}$

Sehingga pengertian informasi merupakan kempulan data yang telah diolah, baik bersifat kualitatif maupun kuantitatif dan memiliki arti lebih luas. Dalam informasi, manusia memerlukan bantuan teknologi sebagai sarana untuk mencari maupun untuk menyebarkan informasi kepada banyak pihak pihak yang dirasa perlu. Selain mengetahui informasi manusia perlu juga mengenal teknologi informasi, apalagi pada era reformasi seperti sekarang dimana kecanggihan teknologi bisa sangat membantu mempermudah pekerjaan manusia.

Teknologi Informasi (TI), atau dalam bahasa Inggris dikenal dengan istilah Information technology (IT) adalah istilah umum yang menjelaskan teknologi apa pun yang membantu manusia dalam membuat, mengubah, menyimpan, mengomunikasikan dan/atau menyebarkan informasi. TI menyatukan komputasi dan komunikasi berkecepatan tinggi untuk data, suara, dan video. Contoh dari Teknologi Informasi bukan hanya berupa komputer pribadi, tetapi juga telepon, TV, peralatan rumah tangga elektronik, dan peranti genggam modern (misalnya ponsel). ${ }^{9}$

\section{Sistem Informasi Manajemen}

Sebelum mengarah pada system informasi manajemen, perlu sekiranya memahami pengertian manajemen. Manajemen berasal dari kata kerja to manage (bahasa Inggris), yang artinya mengurus, mengatur, melaksanakan dan mengelola. ${ }^{10}$ Segala yang diatur dan diurus masuk dalam ranah manajemen. Tujuan menajemen adalah sesuatu yang ingin direalisasikan yang menggambarkan cangkupan tertentu dan menyarankan

\footnotetext{
${ }^{8}$ Ety Rocaety, dkk, system Informasi. . . . 4

${ }^{9}$ http://id.wikipedia.org/wiki/Teknologi_informasi diakses pada tanggal 3 Januari 2013

${ }^{10}$ Faustino Cardoso Gomes, Manajemen Sumber Daya Manusia, (Yogyakarta: ANDI, 2002), 1
} 
pengarahan kepada usaha seorang manajer. ${ }^{11}$ Berdasarkan penjelasan tersebut diatas, dapat diambil empat elemen pokok dalam mencapai tujuan manajemen yaitu: 1) sesuatu yang ingin direalisasikan, 2) Cangkupan, 3) Ketepatan, dan 4) pengarahan.

Sistem informasi manajemen akan dikemukakan beberapa pendapat para ahli secara umum yang dikutip dari buku karangan Eti Rochety sebagai berikut:

a. Gordon B. Davis, 1995 bahwa system informasi manajemen merupakan sebuah system manusia dan mesin yang terpadu untuk menyajikan informasi guna mendukung fungsi operasi, manajemen, dan proses pengambilan keputusan dalam sebuah organisasi.

b. Soetedjo Moeljodiharjo, 1992, system informasi maajemen, yaitu suatu metode yang menghasilkan informasi yang tepat waktu (timely) bagi manajemen tentang lingkungan eksternal dan operasu internal sebuah organisasi, dengan tujuan untuk menunjang pengambilan keputusan dalam rangka memperbaiki perencanaan dan pengendalian.

c. Komarudin, 1997, system informasi manajemen adalah suatu system informasi yang memunginkan pimpinan organisasi mendapatkan informasi dengan kuantitas dan kualitas yang tepat untuk digunakan dalam proses pengambilan keputusan.

d. Robert W. Holmes, 1992, SIM adalah system yang dirancang untuk menyajikan informasi pilihan yang berorientasi kepada keputusan yang diperlukan oleh manajemen guna merencanakan, mengawasi,menilai aktivitas organisasi yang dirancang dalam kerangka kerja yang menitikberatkan pada perencanaan keuntungan, perencanaan penampilan, dan pengawasan pada semua tahap.

e. Robert G. Murdick, 1995, SIM adalah proses komunikasi dimana input direkam, disimpan, dan diambil kembali untuk menyajikan keputusan yang berbentuk output mengenai perencanaan, pengoperasian, dan pengendalian.

f. Joseph F. Kelly, 1990, SIM merupakan perpaduan antara sumber daya manusia dan sumber daya lainnya yang berlandaskan computer yang menghasilkan kumpulan penyimpanan, perolehan kembali, komunikasi, dan penggunaan data untuk tujuan operasi manajemen yng efisien, bagi perencanaan bisnis.

${ }^{11}$ B. Siswanto, pengantar Manajemen, (Jakarta: Bumi Aksara, 2005), 11 
g. Raymond McLeod, Jr., 2003 sistem informasi manajemen yaitu adalah sebuah system berbasis computer yang menyediakan informasi untuk kebutuhan bagi pemaikanya.

h. James A.F. Stoner, 1992, system informasi manajemen yaitu metode yang formal yang menyediakan bagi pihak manajemen informasi yang tepat waktu, dapat dipercaya, untuk mendukung proses pengambilan keputusan bagi perencanaan, pengawasan, dan fungsi operasi sebuah organisasi yang lebih efektif. $^{12}$

Berdasarkan beberapa pendapat para ahli diatas dapat diambil kesimpulan bahwa sistem informasi manajemen merupakan perpaduan antara sumber daya manusia dan aplikasi teknologi informasi untuk memilih, menyimpan, mengolah, dan mengambil kembali data dalam rangka mendukung proses pengambilan keputusan suatuu bidang tertentu. Dapat dikatakan pula bahwa sistem informasi manajemen adalah suatu sistem yang dirancang untuk menyediakan informasi guna mendukung pengambilan keputusan pada kegiatan manajemen (perencanaan, pergerakan, pengorganisasian, dan pengendalian) dalam suatu lembaga.

\section{Pengertian Sumber Daya Manusia}

1. Sumber Daya Manusia

Sarana penting atau sarana utama dalam dari setiap manajer untuk mencapai tujuan yang telah ditentukan terlebih dahulu adalah men atau manusia. ${ }^{13}$ Manusia sebagai sarana pelaksana suatu perencanaan sehingga tidak dapat dipungkiri bahwa sumber daya manusia memegang peranan penting dalam manajerial.

Sumber daya manusia merupakan salah satu sumber daya yang terdapat dalam organisasi, meliputi semua orang yang melakukan aktivitas. Secara umum, sumber daya yang terdapat dalam suatu organisasi atau lembaga bisa dikelompokkan menjadi dua macam, yaitu: 1) Sumber Daya

\footnotetext{
${ }^{12}$ Ety Rocaety, dkk, system Informasi . . . . 12-13

${ }^{13}$ M. Manullang, Dasar-dasar Manajemen, (Jakarta: Ghalia Indonesia, 1983), 17
} 
Manusia (Human Resource) dan 2) Sumber Daya non- Manusia (nonHuman Resource). Yang termasuk dalam kelompok sumber daya nonmanusia ini antara lain modal, mesin, teknologi, bahan-bahan (material), dan lain-lain.

2. Unsur-unsur Sumber Daya Manusia

Unsur-unsur sumber daya manusia meliputi kemampuankemampuan, sikap, nilai-nilai, kebutuhan-kebutuhan, dan karakteristikkarateristik demografisnya. Unsure-unsur sumber daya manusia tersebuut sangat dipengaruhi oleh lingkungan sekitarnya, seperti norma-norma dan nilai-nilai masyarakat, tingkat pendidikan dan peluang-peluang yang tersedia. Unsure-unsur tersebut pada gilirannya akan mempengaruhi peranan dan perilaku manajer dalam organisasi. Orang-orang dalam organisasi dapat dibedakan satu dengan yang lainnya berdasarkan variablevariabel tersebut. Orang-orang yang terlibat dalam organisasi biasanya memiliki karakteristik dalam hal unsure-unsur tersebut yang saling berbeda antara satu dengan yang lainnya, termasuk manajernya. Perbedaan-perbedaan seperti itu sangat penting untuk diketahui oleh manajer, dan sedapat mungkin mengakomodasikannya. Pengakuan atas perbedaan potensi-potensi itu juga menuntut adanya penyesuaian manajer terhadap karakteristik-karakteristik tersebut. Sebaliknya, peranan dan perilaku manajer mempengaruhi unsure-unsur sumber daya manusia, dan yang ini seterusnya juga akan berpengaruh terhadap lingkungannya. Secara sederhana kaitan-kaitan tersebut digambarkan dibawah ini. 


\section{Lingkungan}

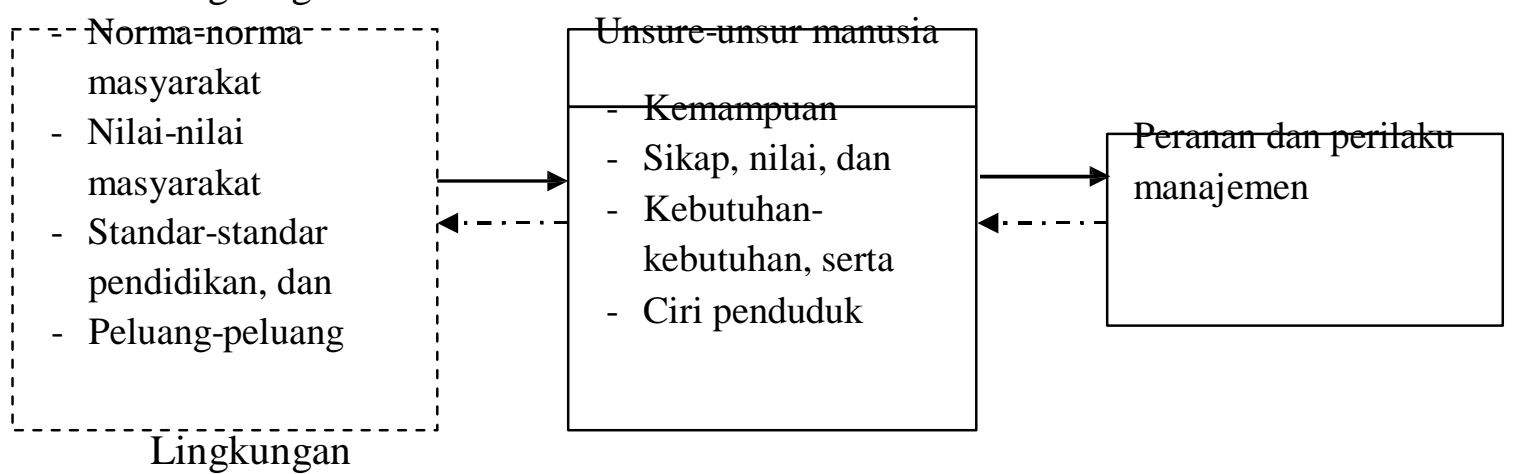

Gambar 1.6 Hubungan unsure-unsur manusia dengan lingkungan dan manajemen lingkungan ${ }^{14}$

\section{Manajemen Sumber Daya Manusia (MSDM)}

Dalam manajemen sumber daya manusia (MSDM) pembahasan difokuskan pada unsure manusia pekerja. Manajemen sumber daya manusia adalah ilmu dan seni mengatur hubungan dan peranan tenaga kerja, agar efektif dan efisien membantu terwujudnya tujuan. ${ }^{15}$ Jadi secara sederhana pengertian manajemen sumber daya manusia adalah mengelola sumber daya manusia. Dalam pengelolaan sumber daya manusia tentunya akan selalu menemui konflik yang komplek karena jumlah sumber daya manusia yang banyak. Pengelolaan sumber daya manusia dimaksudkan untuk mampu mengontrol, mengkondisikan dan usaha pencapaian tujuan yang telah direncanakan. Pengelolaan sumber daya manusia yang baik tidak hanya menguntungkan lembaga karena akan mendapatkan hasil kerja yang baik, namun juga menguntungkan bagi para pelaku sumber daya manusia itu sendiri. Kesejahteraan sumber daya manusia menjadi hal yang selalu diharapkan untuk didapat oleh setiap individu sumber daya manusia tersebut.

\footnotetext{
${ }^{14}$ Faustino Cardoso Gomes, Manajemen. . . ., 27

${ }^{15}$ Malayu S. P. Hasibuan, Manajemen: Dasar, Pengertian, dan Masalah, (Jakarta: Bumi Aksara, 2003), 21
} 


\section{Tujuan Sistem Sumber Daya Manusia}

Berikut ini data yang merefleksikan item-item besar dalam serangkaian tujuan yang berhubungan dengan sistem sumber daya manusia menurut Armstrong yang dikutip oleh Eugene:

a. Tujuan perusahaan dapat dicapai melalui sumber daya yang paling bernilai tenaga kerja.

b. Untuk mempertinggi baik kinerja individu dan organisasional, orang diharapkan mengatur dirinya untuk mencapai kesuksesan organisasi.

c. Seperangkat kebijakan dan praktek personil yang melengkapi kinerja organisasi yang efektif merupakan prasyarat bagi perusahaan untuk menggunakan sumber daya secara optimum ketika berusaha mencapai tujuan bisnis.

d. Integrasi kebijakan sumber daya manusia tujuan bisnis harus dicari

e. Kebijakan sumber daya manusia harus mendukung budaya perusahaan yang tepat, atau perubahan budaya kea rah yang lebih baik jika budaya yang sekarang dianggap kurang baik.

f. Iklim organisasional yang mendukung kreativitas individual yang memungkinkan usaha penuh semangat harus dipelihara. Hal ini menyediakan tanah yang lapang untuk promosi kerja tim, inovasi dan manajemen kualitas total.

g. Penciptaan system organisasi fleksibel yang responsive dan adaptif mebantu perusahaan untuk mencapai tujuan yang tepat dalam lingkkungan kompetitif.

h. Sebuah penentu fleksibilitas individual dalam jumlah jam kerja dan fungsi yang dilaksanakan.

i. Ketentuan tugas dan kondisi organisasi yang mendukung orang untuk mencoba merealisasikan potensinya terhadap pekerjaan.

j. Pemeliharaan dan peningkatan kemampuan baik tenaga kerja maupun produk/ jasa. ${ }^{16}$

Berdasarkan pada pemaparan diatas, maka dapat ditarik kesimpulan bahwa dalam mencapai tujuan suatu lembaga tidak cukup mengandalkan system yang digunakan dalam lembaga tersebut, atau hanya mengandalkan sumber daya manusia yang ada di dalamnya, sumber daya manusia tidak dapat diforsir terus menerus untuk mencapai suatu tujuan lembaga. Namun yang utama adalah adanya kerjasama, saling keterkaitan dan saling mendukung

\footnotetext{
${ }^{16}$ Eugene Mckenna dan Nic Beech, The Essence of Manajemen Sumber Daya Manusia, terj. Totok Budi Santoso, (Yogyakarta: ANDI, 2001), 16-17
} 
antara system dan sumber daya manusia agar dapat tercapai tujuan lembaga secara maksimal.

\section{Fungsi Sistem Informasi Manajemen dalam Pendidikan}

Dalam dunia pendidikan keberadaan sistem informasi merupakan salah satu yang tidak dapat dipisahkan dari aktivitas pendidikan. Dalam sebuah lembaga pendidikan memiliki komponen-komponen yang diperlukan untuk menjalankan operasional pendidikan, seperti siswa/mahasiswa, sarana-sarana, struktur organisasi, proses, sumber daya manusia (tenaga pendidik), dan biaya organisasi. Adapun system informasi terdiri dari komponen-komponen pendukung lembaga pendidikan untuk menyediakan informasi yang dibutuhkan pihak pengambil keputusan saat melakukan aktivitas pendidikan.

System informasi terbentuk dari komponen-komponen perangkat keras (hardware), perangkat lunak (Software), dan perangkat manusia (Brainware). Dalam teori manajemen untuk menjalankan sebuah lembaga pendidikan, strategi lembaga pendidikan dan strategi system informasi harus saling mendukung sehingga dapat menciptakan keunggulan bersaing (competitive advantage) lembaga pendidikan yang bersangkutan.

Dalam mengidentifikasu daya saing lembaga pendidikan yang marktable dan sellable ada beberapa kekkuatan yang harus menjadi proritas perhatisn para pengambil kebijakan yang secara ofensif dan defensive menggunakan tegnologi informasi. Michael Porter, 1995, dalam manajemen strategi memperkenalkan Five Forces (lima kekuatan) yang harus dicermati oleh pihak pimpinan lembaga pendidikan yang skemanya digambarkan

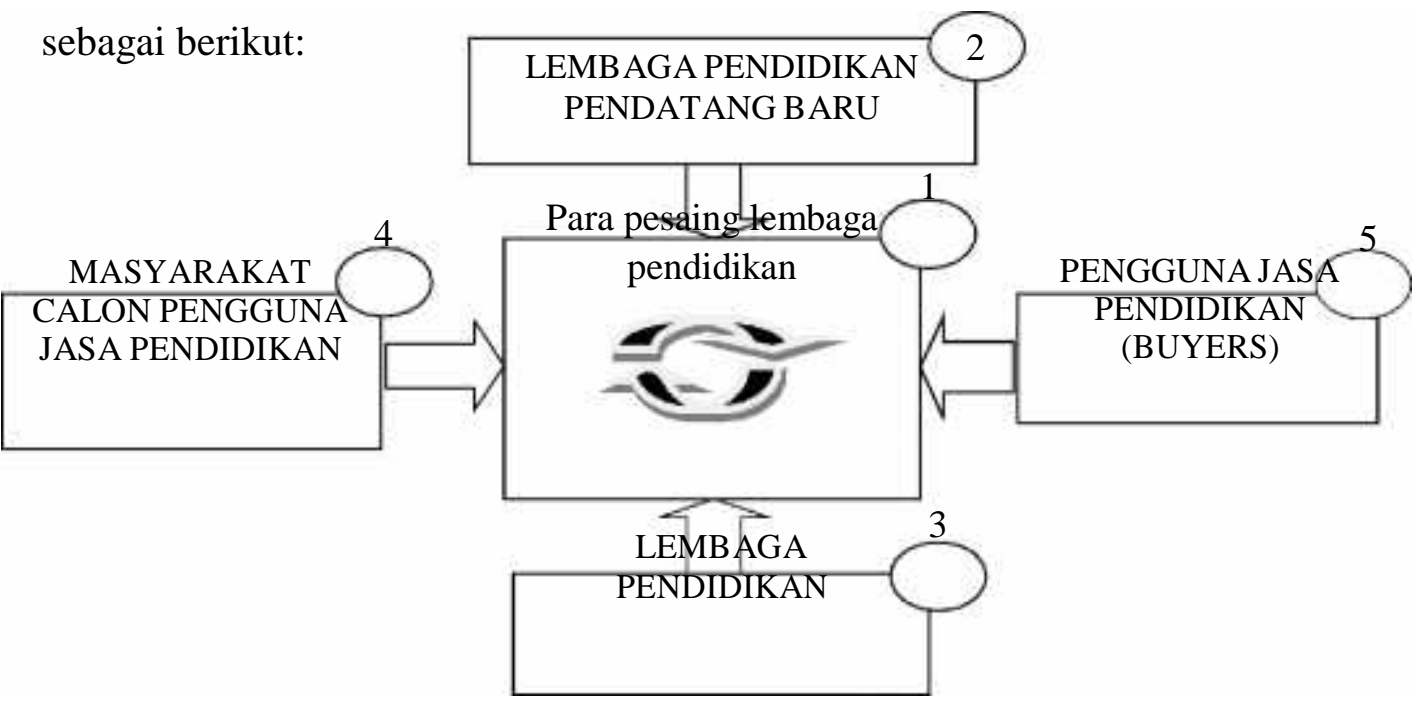


Gambar 1.1 Pengertian Sistem ${ }^{17}$

Setiap lembaga yang ingin mempertahankan eksistensinya harus benarbenar berusaha memenangkan persaingan dengan meraih jumlah pengguna jasa pendidikan melalui berbagai strategi, seperti meningkatkan kapabilitas penguasaan tegnologi informasi.

Menurut indraajit yang dikutip oleh Eti, strategi system informasi manajemen merupakan sub bagian dari sebuah Work plan lembaga pendidikan karena peranan system informasi dinilai sangat kritikal dalam mendorong kelangsungan hidup sebuah lembaga pendidikan. Tiga pilar utama yang harus diperhatikan dalam menyusun strategi tersebut adalah sebagai berikut: 1) Strategi system informasi, 2) Kebutuhan akan strategi tegnologi informasi, dan 3) Strategi system informasi dan strategi teknologi informasi. ${ }^{18}$ Ketiga pilar ini hendaknya dapat dijadikan acuan dalam menerapkan system informasi manajemen utamanya dalam lembaga pendidikan.

Pengelolaan suatu lembaga atau perusahaan tidak lepas dari bantuan atau membutuhkan lembaga yang lain sebagai penunjang untuk mencapai tujuan, berikut pula dengan lembaga pendidikan. Tentunya banyak lembaga yang dapat membantu lembaga pendidikan dalam mencapai tujuan manajemennya utamanya dalam bidang teknologi informasi. System kerjasama suatu lembaga dengan satu atau lebih lembaga disebut dengan IOS (Inter Organizational System) yaitu dua atau lebih organisasi pendidikan bekerjasama dalam pemakaian tegnologi informasi.

Lembaga pendidikan yang tertarik melakukan IOS memiliki dasar alasan diantaranya adalah: 1) Program baru, 2) Pelayanan baru, 3) Efisiensi, 4) Hubungan antar lembaga pendidikan dan masyarakat, 5) Menggunakan jasa lain untuk membantu melakukan aktiifitas pendidikan, 6) Membangun citra lembaga pendidikan, 7) Operasi bersama, 8) Aliansi strategis. ${ }^{19}$ Fenomena yang muncul belakangan ini tidak lepas dari kemajuan teknologi informasi

\footnotetext{
${ }^{17}$ Ety Rocaety, dkk, system Informasi ....hal 18

${ }^{18}$ Ibid.. 22

${ }^{19}$ Ibid.... 22
} 
yang semakin hari semakin canggih, sehingga membuat lembaga manapun untuk terus menambah wacana dan wawasan tentang teknologi informasi. Dengan melaksanakan program IOS akan mempermudah lembaga dalam mengembangkan usaha karena selalu bisa mengikuti kemajuan sesuai permintaan pasar.

\section{Hubungan Sistem Informasi Manajemen dengan Sumber Daya Manusia}

Kecepatan tegnologi informasi sangat tinggi sehingga sangat sulit bagi lembaga pendidikan untuk menyusun strategi mempertahankan eksistensinya dalam jangka panjang. Ada tiga kunci utama yang mendukung teknologi informasi untuk dijadikan asset lembaga pendidikan dalam jangka panjang yaitu: 1) Sumber Daya Manusia, 2)Teknologi, 3) Relasi. ${ }^{20}$

Sumber daya manusia yang dimaksud disini adalah para staf penanggungjawab perencanaan dan pengembangan teknologi informasi pada suatu lembaga pendidikan. Dengan demikian para staf tersebut benar-benar memiliki tanggung jawab terhadap pengoperasian teknologi informasi, memiliki kompetensi untuk memecahkan masalah yang dihadapi lembaga pendidikan sehari-hari, dan selalu mencari kesempatan menggunakan tegnologi informasi untuk kemajuan lembaga pendidikan tersebut. Melalui kombinasi aktivitas pelatihan, pengalaman bekerja, kemampuan manajerial, kepemimpinan yang berkualitas, staf teknologi informasi tersebuta akan memiliki pengetahuan dan kompetensi yang dibutuhkan. Factor SDM yang menjadi staf pengembangan teknologi perlu memiliki 3 dimensi sebagai berikut:

1. Keahlian teknis sumber daya manusia sangatt dibutuhkan dalam dunia pendidikan, mengingat cepatnya perkembangan teknologi informasi yang terjadi. Keahlian teknis yang dimiliki seorang staf teknologi informasi terutama untuk selalu mempelajari hal-hal baru.

2. Pengetahuan mengenai dunia pendidikan biasanya diperoleh dari hasil interaksi antar SDM yang terlibat dalam dunia pendidikan, dan mengetahui

${ }^{20}$ Ibid..... 25 
proses operasional lembaga pendidikan yang menggunakan bantuan teknologi informasi serta kemungkinan untuk meningkatkan nilai tambah bagi lembaga pendidikan tersebut.

3. Orientasi pada pemecahan masalah. Hal ini tidak terbatas pada karakteristik SDM secara tradisional yang hanya terpaku pada tugas-tugas rutin. Akan tetapi, SDM yang dibutuhkan cenderung merupakan kumpulan orang yang selalu berfikir kritis dan kreatif dalam memecahkan masalah yang terjadi pada lembaga pendidikan.

Seluruh infrastruktur teknologi informasi, termasuk perangkat keras dan perangkat lunak dipergunakan secara bersama-sama dalam proses operasional lembaga pendidikan karena merupakan tulang punggung terciptanya system yang terintegrasi, dengan biaya yang relative terjangkau, untuk biaya operasional, pengembangan, maupun biaya pemeliharaan. System informasi disesuaikan dengan kebutuhan jaringan yang tersedia pada lembaga pendidikan. Sehingga lembaga pendidikan harus terus mengontrol kondisi infrastruktur teknologi informasinya.

Relasi antara teknologi informasi dengan lembaga pendidikan lebih mengarah pada proses pengambilan keputusan. Menjalin suatu relasi berarti membagi resiko dan tanggung jawab. Dalam mewujudkan relasi membutuhkan dukungan tinggi SDM, dalam hal ini SDM yang dimaksud adalah pemegang kekuasaan tertinggi dalam lembag tersebut. Pimpinan lembaga pendidikan akan bertanggung jawab pada aplikasi teknologi informasi yang berorientasi terhadap proses bukan berdasarkan fungsi organisasi. Pimpinan lembaga juga diharapkan mampu memutuskan skala prioritas pengembangan dan implementasi dari tknologi informasi berdasarkan skala kepentingan lembaga pendidikan.

\section{Peran Sistem Informasi Manajemen dalam Pengambilan Keputusan Bidang Pendidikan}


Menurut George R. Terry dalam Iqbal Hasan, yang dikutip oleh Eti. ${ }^{21}$ Salah satu peran system informasi manajemen adalah untuk mengambil keputusan dalam suatu lembaga pendidikan. Pengambilan keputusan adalah pemilihan alternative perilaku tertentu dari dua atau lebih alternative yang ada dan menurut Ibnu Syamsi unsure-unsur dalam pengambilan keputusan yang harus dipertimbangkan adalah: 1) Tujuan dari pengambilan keputusan, 2) Identifikasi alternative-alternatif keputusan untuk memecahkan masalah dipilih untuk mencapai tujuan tersebut, 3) Perhitungan mengenai factor-faktor yang tidak dapat diketahui sebelumnya, dan 4) Sarana/ alat untuk mengevaluasi / mengukur hasil dari suatu pengambilan keputusan. Unsureunsur pengambilan keputusan dapat digunakan oleh kepala sekolah untuk terlebih dahulu mengkaji dan mempertimbangkan mengenai tujuan pengambilan keputusan, manfaat dan dampat dari pengambilan keputusan.

Pengambilan keputusan di dasarkan pada lima hal, yaitu: 1) Intuisi, 2) Pengalaman, 3) Fakta, 4) Wewenang, dan 5) Rasional. Kelima hal ini saling berhubungan dan berkaitan sehingga tidak dapat dipisahkan atau hanya digunakan salah satu saja. Selain dasar dalam pengambilan keputusan, perlu juga memperhatikan factor-faktor yang mempengaruhi pengambilan keputusan. Adapun factor-faktor yang dimaksud adalah: 1) Posisi/ kedudukan, 2) Masalah, 3) Situasi, 4) Kondisi, dan 5) Tujuan.

Untuk menghindari kesalah dalam pengambilan keputusan hendaknya pimpinan lembaga pendidikan atau kepala sekolah perlu mempertimbangkan dasar-dasar dan factor-faktor diatas. Pengambilan keputusan tentu diharapkan mampu membawa perubahan yang lebih baik dan tidak menjadikan suatu lembag tertinggal kemajuan teknologi.

\section{Kesimpulan}

Sistem merupakan satu kesatuan yang saling keterkaitan. Perkembangan suatu system akan selalu dipengaruhi oleh teknologi informasi. Dalam mensiasati ketertinggalan teknologi informasi maka perlu adanya

${ }^{21}$ Ibid..... 151 
pengolahan sistem informasi yang dinamakan dengan sistem informasi manajemen.

Manusia sebagai sarana pelaksana suatu perencanaan sehingga tidak dapat dipungkiri bahwa sumber daya manusia memegang peranan penting dalam manajerial. Sumber daya manusia merupakan salah satu sumber daya yang terdapat dalam organisasi, meliputi semua orang yang melakukan aktivitas.

Dalam sebuah lembaga pendidikan memiliki komponen-komponen yang diperlukan untuk menjalankan operasional pendidikan, seperti siswa/mahasiswa, sarana-sarana, struktur organisasi, proses, sumber daya manusia (tenaga pendidik), dan biaya organisasi. Adapun system informasi terdiri dari komponen-komponen pendukung lembaga pendidikan untuk menyediakan informasi yang dibutuhkan pihak pengambil keputusan saat melakukan aktivitas pendidikan.

Dalam upaya mempertahankan eksistensi suatu lembaga dalam mengimbangi kemajuan sistem informasi manajemen, maka sumber daya manusia sebagai suatu yang pertama untuk dapat mewujudkan tujuan yang telah direncanakan suatu lembaga. Selain sumber daya manusia diperlukan pula teknologi dan relasi.

Perkembangan sistem informasi bisa mempengaruhi pengambilan keputusan dalam suatu lembaga. Diharapkan pengambilan keputusan merupakan proses menuju ke arah yang lebih baik sehingga dengan pegetahuan yang bertambah dari sistem informasi akan menambah wacana, pertimbangan dan akhirnya memutuskan dengan tepat. 


\section{DAFTAR RUJUKAN}

Cardoso Gomes, Faustino, Manajemen Sumber Daya Manusia, (Yogyakarta: ANDI, 2002)

H. M., Jogiyanto, Model Kesuksesan Sistem Informasi Tegnologi,

(Yogyakarta: ANDI, 2007).

Manullang,M., Dasar-dasar Manajemen, (Jakarta: Ghalia Indonesia, 1983)

Marimin, dkk, Sistem Informasi Manajemen Sumber Daya Manusia, (Jakarta: Grasindo, 2006)

Mckenna dan Nic Beech, Eugene, The Essence of Manajemen Sumber Daya Manusia, terj. Totok Budi Santoso, (Yogyakarta: ANDI, 2001)

P. Siagian, Sondang, Manajemen Sumber Daya Manusia, (Jakarta: Bumi Aksara, 2003)

Rocaety, Ety, dkk, system Informasi Manajemen Pendidikan, (Jakarta: PT Bumi Aksara, 2005)

Siswanto,B., pengantar Manajemen, (Jakarta: Bumi Aksara, 2005)

S. P. Hasibuan, Malayu, Manajemen: Dasar, Pengertian, dan Masalah, (Jakarta: Bumi Aksara, 2003)

http://id.wikipedia.org/wiki/Teknologi_informasi diakses pada tanggal 18 Januari 2016 